\title{
TIMING PARAMETERS OF PYROTECHNIC IGNITER BASED ON MAGNESIUM POWDER
}

\author{
Vojtěch PELIKÁN ${ }^{1}$, Richard KURACINA ${ }^{2}$, Zuzana SZABOVÁ ${ }^{2}$ \\ ${ }^{1}$ UnIVERSITY OF PARDUBice, FACULTY OF CHEMICAL TECHNOLOGY, INSTITUTE OF ENERGETIC \\ Materials, Doubravice 41, 53210 PARdubice, CZECH RePubliC \\ ${ }^{2}$ SLOVAK UNIVERSITY OF TECHNOLOGY IN BRATISLAVA, FACULTY OF MATERIALS SCIENCE \\ AND TECHNOLOGY IN TRNAVA, INSTITUTE OF INTEGRATED SAFETY, \\ UlicA JÁNA BotTu 2781/25, 91724 TRNAVA, SLOVAKIA \\ e-mail: vojtech.pelikan@upce.cz,richard.kuracina@stuba.sk,zuzana.szabova@stuba.sk \\ Received: 13.05.2019, Accepted: 11.06.2019, Published: 25.07.2019
}

\begin{abstract}
Chemical igniters are used in the study of dispersed dusts. Energy released during their use is defined by EN 14034 at $2 \times 5 \mathrm{~kJ}$. The Standard does not define the exact composition of the pyrotechnic mixture. The condition of using the igniter is to release energy according to the Standard. This article is focused on pyrotechnic composition with magnesium powder. It deals with various ways of activating, preparing and sealing the pyrotechnic mixture in the igniter. These values are important for setting up a device for studying the explosive properties of dispersed dusts.
\end{abstract}

\section{Key words}

Igniter, chemical igniter, dispersed dust, magnesium powder

\section{INTRODUCTION}

Energetic materials are used in engineering applications since they rapidly release large amounts of energy that can be used to perform work. Explosives represent a specific type of energetic materials; pyrotechnics are a specific type of explosive, known as low explosives. Pyrotechnics are mixtures of fuel, oxidizer, and sometimes additives for effects, such as colour or smoke. Such pyrotechnic mixtures chemically react with fast combustion velocities, known as deflagrations proceeding through the pyrotechnic material more slowly than the local speed of sound. Alternatively, high explosives react in a detonation at a speed greater than the local speed of sound. Pyrotechnics are especially useful energetic mixtures owing to their output characteristics, such as the heat and gas generation and the light and smoke production. Pyrotechnic mixtures are used for a variety of everyday applications, including fireworks, rifles, road flares, the motor vehicle seat belt restraints and airbags, and solid fuel rocket boosters $[1,2,3]$. 
Magnesium powder is a common combustible material in pyrotechnic formulas. It has excellent light-emitting properties, high exotherm, easy ignition, and stable combustion, while being widely used in flash agents, illuminating agents, flare agents, fireworks, etc. [4].

Magnesium is a very reactive metal and makes an excellent fuel under the proper conditions. It is oxidized by moist air to form magnesium hydroxide. The chlorate and perchlorate salts, in the presence of moisture, will oxidize magnesium metal, destroying the pyrotechnic effect during storage. Nitrate salts appear to be considerably more stable with magnesium. Magnesium exhibits heat of combustion of $5.9 \mathrm{kcal} / \mathrm{g}$, a melting point of $649{ }^{\circ} \mathrm{C}$, and a low boiling point of $1107^{\circ} \mathrm{C}$. This low boiling point allows for excess magnesium in the mixture to vaporize and burn with oxygen in the air in the pyrotechnic flame, providing additional heat (and light) in flare compositions [5].

The role of pyrotechnic igniter is to generate the initial flame which induces dust particles to produce a flame kernel able to allow self-propagation. [7] Tests are preformed according to international standards, for example the EN 14034 series or ASTM E1226. In order to determine the explosion characteristics, the dust samples are dispersed in the air and ignited using two pyrotechnical igniters with the energy contents of $1 \mathrm{~kJ}$ or $5 \mathrm{~kJ}$. Since the igniters could influence the test results, they are defined in the standards [5].

For ignition of a combustible dust-air mixture to result in explosion, there needs to be an ignition source of the adequate initiating energy which is generally stronger than for gases. The type and strength of the ignition source have a significant effect on the initiation and progress of the explosion. In the dust explosion studies, due to difficulties encountered in the ignition of some dusts, strong ignition sources such as pyrotechnic igniters or black powder (guncotton) have to be used. The energy of a pyrotechnic igniter could strongly affect some explosion parameters, such as the $K_{\mathrm{st}}$, values and the lower explosion limits of dust explosions in the standard [8].

Dusts can require a significantly higher energy than gases to be ignited: as such, pyrotechnical igniters (made of $40 \%$ of zirconium, $30 \%$ of barium nitrate and $30 \%$ of barium peroxide) used for dust testing provide the energies of several kilojoules, while fuse wires employed to ignite gaseous mixtures have energies of only several joules [6].

Due to various disadvantages of the pyrotechnical igniters such as high energy input in comparison to most of the ignition sources in practice, high costs and legal requirements concerning its storage and use, the need for alternative ignition sources keeps arising again and again. Such alternative ignition sources should be cheap, readily available, and the operator should be able to use them without a certificate of authorisation. In addition, the ignition energy should be adjustable over a wide range and, if possible, allow for the energy amounts less than $1000 \mathrm{~J}$. In comparison to the ignition energies described in the test standards, such energy amounts are more realistic for most of the ignition sources found in practice, such as electrostatic discharges, mechanical sparks or hot surfaces [5].

For measuring the lower explosive limit, the igniter must be of the optimum strength, otherwise limit values too high or low are obtained. Pyrotechnic igniters which are usually used for igniting dusts produce a significant pressure by themselves [9].

Pyrotechnic igniters were described by Kundu [10]. The igniters with higher ignition energies are constructed with higher amounts of ignition powders and produce higher flame areas once getting ignited. The overall burning rate increases with the increased flame area; and therefore, the explosion pressure increases with increasing the ignition energy. For high energy pyrotechnic igniters, this effect decreases owing to the thermodynamic limit of explosion pressure [10]. 


\section{MATERIALS AND METHODOLOGY OF EXPERIMENT}

Pyrotechnic compositions are usually mechanical mixtures of chemicals. The purpose of pyrotechnics is to light, heat, sound, smoke or ignite when burning (or explosion). Effects are used in the military technology or in industry, transportation, agriculture or the film industry.

Safe handling of the pyrotechnic composition is possible when an alkali metal nitrate is used as an oxidizer. The compositions containing metal powders with chlorates, perchlorates or peroxides are more sensitive to friction and impact.

This article describes the parameters of a pyrotechnic composition composed of $75 \% \mathrm{wt}$. potassium nitrate, $15 \% \mathrm{wt}$. magnesium powder and $10 \% \mathrm{wt}$. charcoal. The size of all particles is up to 90 microns. For the tests described in this article, an untreated pyrotechnic mixture, compressed and granulated with addition of 5\% nitrocellulose was used.

Below is the example of a simple reaction that can occur during burning of pyrotechnic composition (Equation 1):

$$
4 \mathrm{KNO}_{3}+2 \mathrm{Mg}+\mathrm{C}=4 \mathrm{KNO}_{2}+2 \mathrm{MgO}+\mathrm{CO}_{2}
$$

The igniter body forms a closed space with a cover. As a cover, a piece of paper, a thin plastic film (PVC), an aluminum foil or a plastic tray (polyethylene) may be used. A deflector is located on the igniter to direct the flow of burning particles.

The igniter charge is activated by a fuse head. The ignition of fuse head is activated by an electric pulse with $2.1 \mathrm{~A}$ at minimum.

Ignition of the igniter was recorded by a highspeed camera (1000 and $8000 \mathrm{fps})$. The ignition time of the igniter was measured optically (by LED) or the camera was triggered by a lighter.

\section{ATTAINED RESULTS}

In the first step, the characteristics of the fuse head activation were determined. The measured time parameters are shown in Table 1. The photographic record of significant parameters is shown in Figures 1 and 2.

Table 1 Time characteristics of fuse heads $\left(\mathrm{t}_{0}=0.010 \mathrm{~s}\right)$ at $8000 \mathrm{fps}$

\begin{tabular}{|l|l|l|}
\hline & EMP-SO (Fig 1.) & EPZ-2S (Fig 2.) \\
\hline first change $[\mathrm{ms}]$ & 0.375 & 0.250 \\
\hline first hot particle $[\mathrm{ms}]$ & 12.375 & 0.750 \\
\hline fire of fuse head $[\mathrm{ms}]$ & 15.000 & 2.375 \\
\hline
\end{tabular}

Table 2 shows the measured time characteristics of the igniter sealed with a PVC foil (thickness $0.15 \mathrm{~mm}$ ) of a free-flowing pyrotechnic composition. 
Table 2 Time characteristics of igniter with various compositions

\begin{tabular}{|l|l|l|l|l|}
\hline & \multicolumn{1}{|c|}{$\begin{array}{l}\text { first visible } \\
\text { change [ms] }\end{array}$} & $\begin{array}{l}\text { first visible } \\
\text { flame [ms] }\end{array}$ & $\begin{array}{l}\text { full flame } \\
{[\mathbf{m s}]}\end{array}$ & $\begin{array}{l}\text { max. size of } \\
\text { flame [mm] }\end{array}$ \\
\hline $\begin{array}{l}\text { free-flowing composition, EMP-SO fuse } \\
\text { head (8000 fps) (Fig. 3) }\end{array}$ & 32.750 & 32.875 & 35.750 & 100 \\
\hline $\begin{array}{l}\text { free-flowing composition, EPZ-2S fuse } \\
\text { head (8000 fps) (Fig. 4) }\end{array}$ & 23.250 & 23.375 & 27.125 & 150 \\
\hline $\begin{array}{l}\text { free-flowing composition with booster } \\
\text { (KClO } 3 \text { /Mg), EMS-SO fuse head (1000 } \\
\text { fps, start at frame 624) (Fig. 5) }\end{array}$ & $\begin{array}{l}28 \\
\text { (f. 652) }\end{array}$ & $\begin{array}{l}30 \\
\text { (f. 654) }\end{array}$ & $\begin{array}{l}37 \\
\text { (f. 661) }\end{array}$ & N/A \\
\hline
\end{tabular}

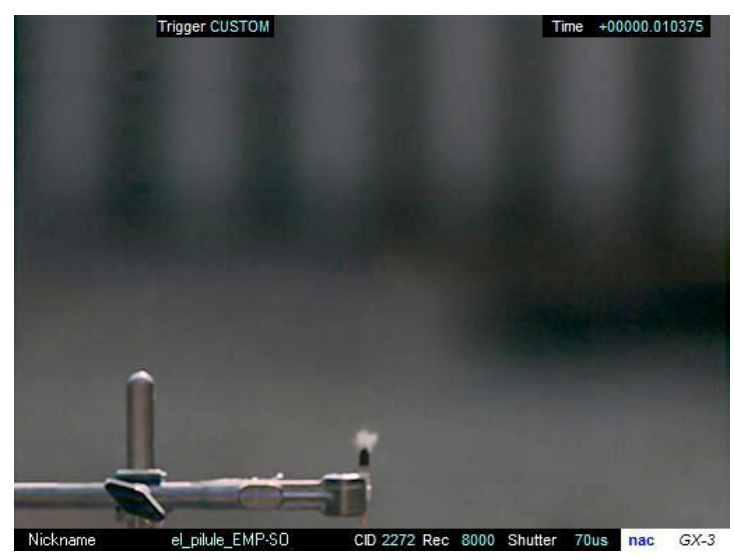

a) first change after fuse head activation

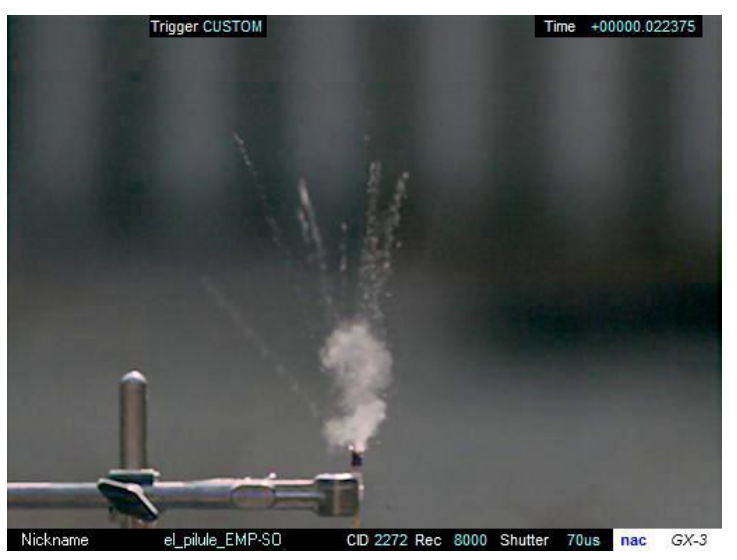

b) first visible hot particle

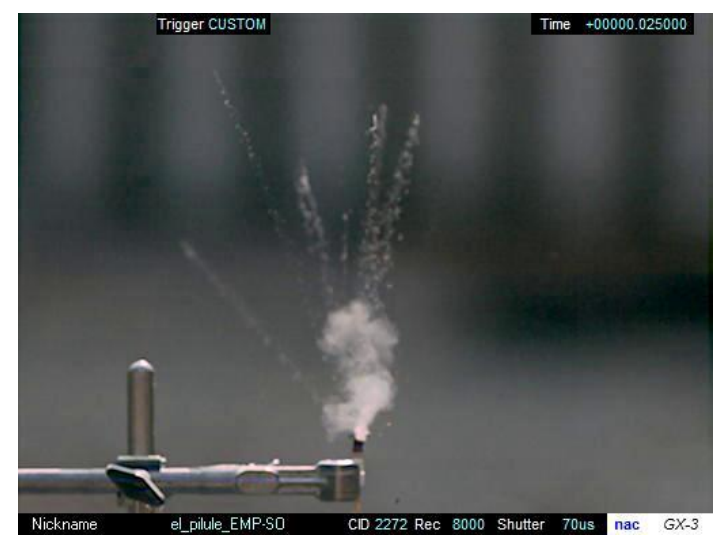

c)fire of fuse head

Fig. 1 EMP-SO fuse head burning 


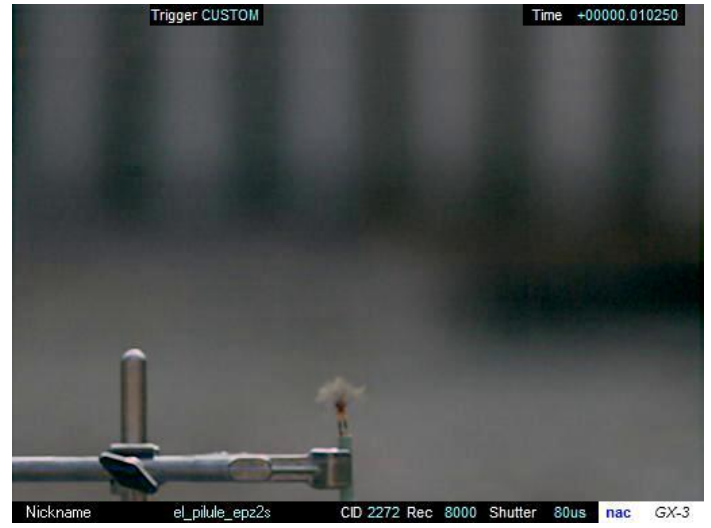

a) first change after fuse head activation

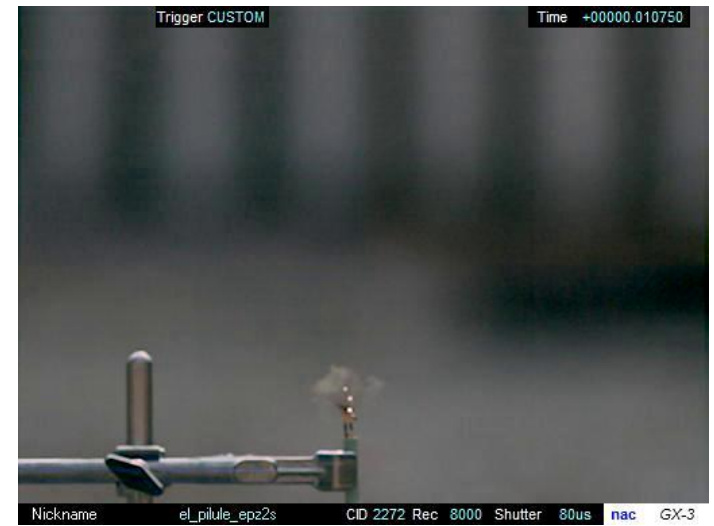

b) first visible hot particle

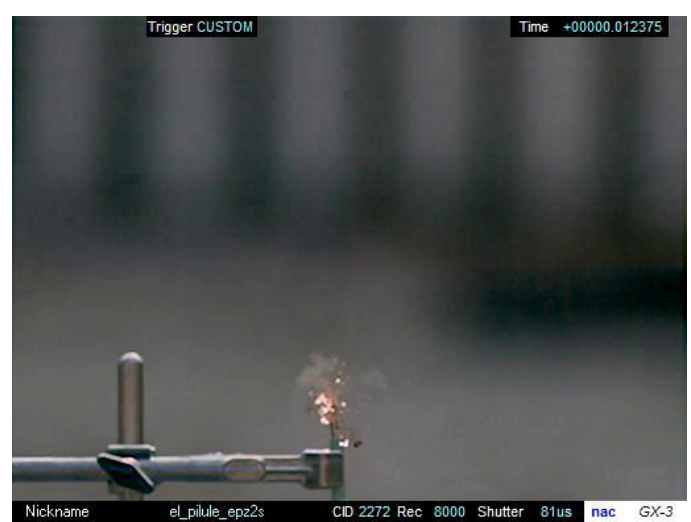

c) fire of fuse head

Fig. 2 EPZ-2S fuse head burning

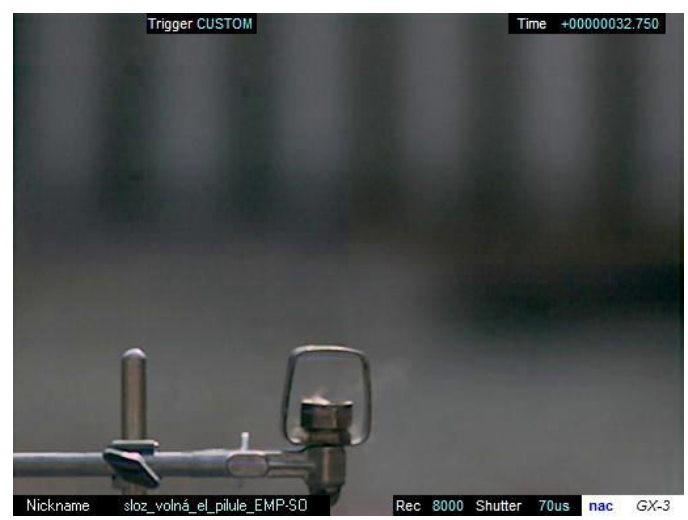

a) first visible change after activation

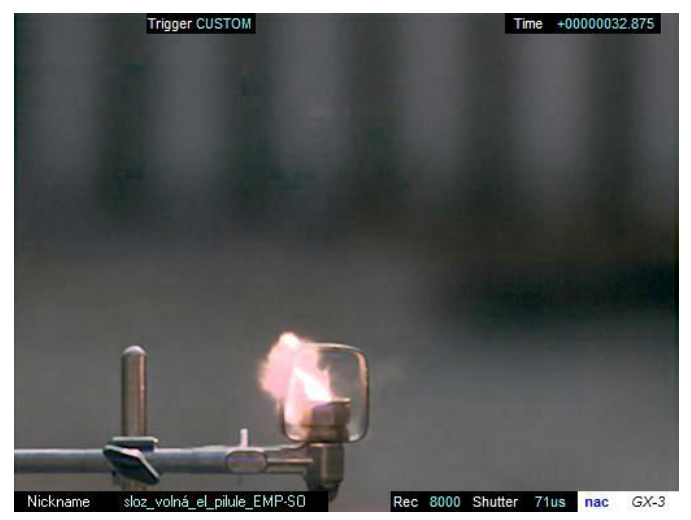

b) first visible flame after activation

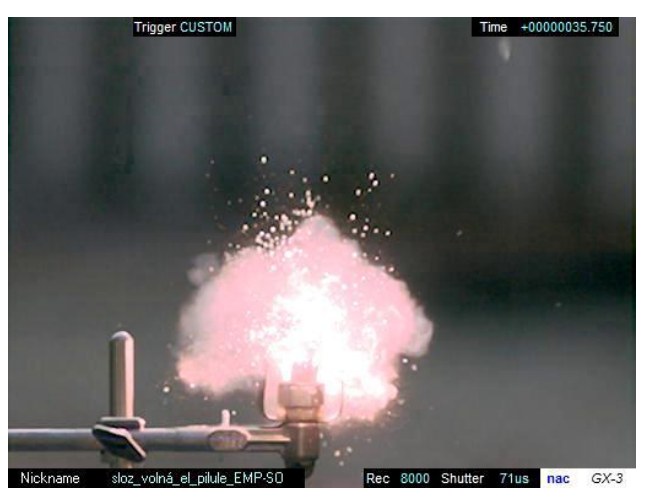

c) full flame

Fig. 3 Igniter with EPS-SO fuse head burning 


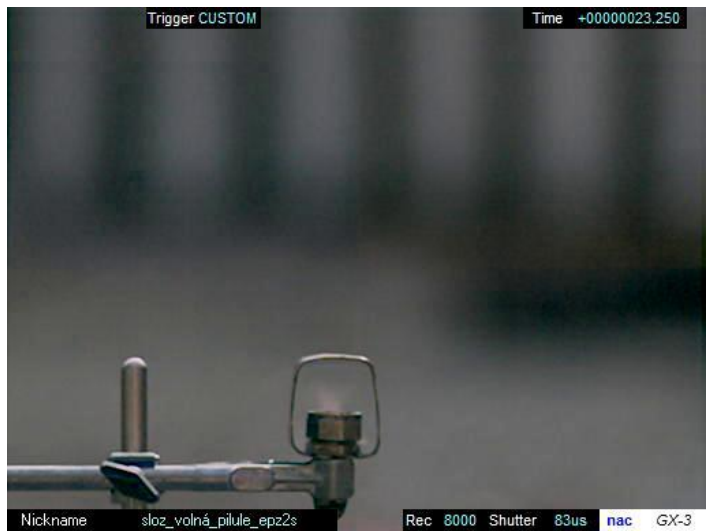

a) first visible change after activation

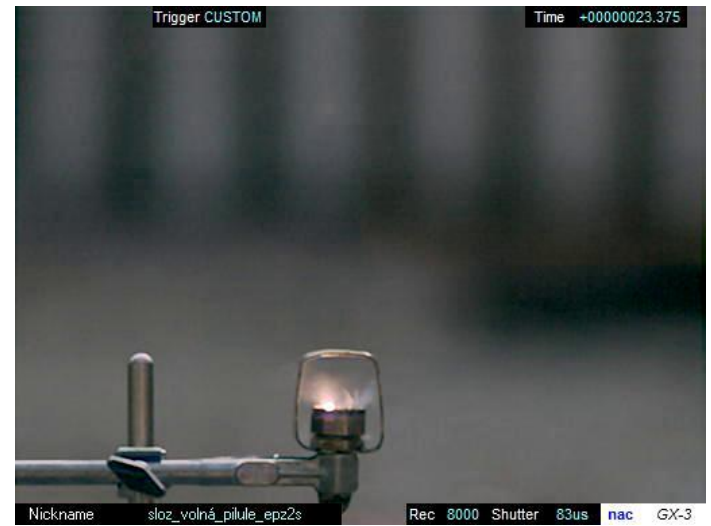

b) first visible flame after activation

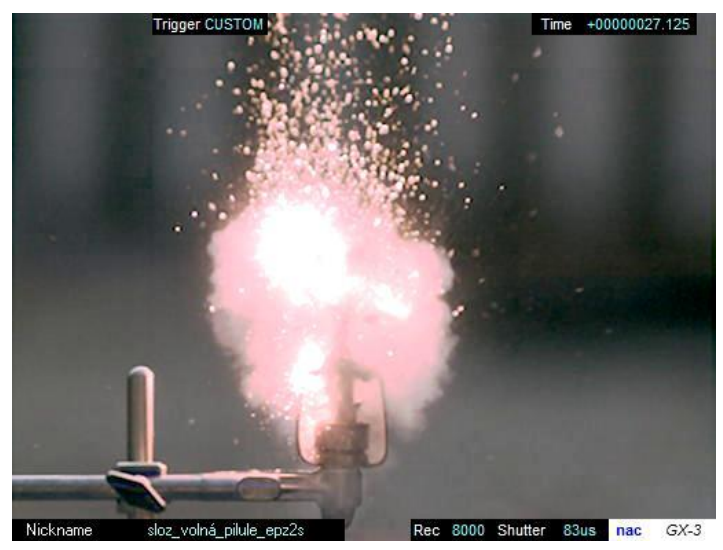

c) full flame

Fig. 4 Igniter with EPZ-2S fuse head burning

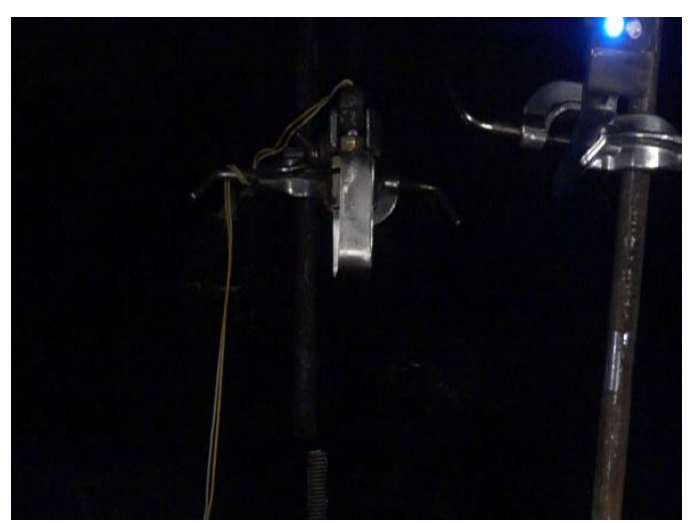

a) first visible change after activation

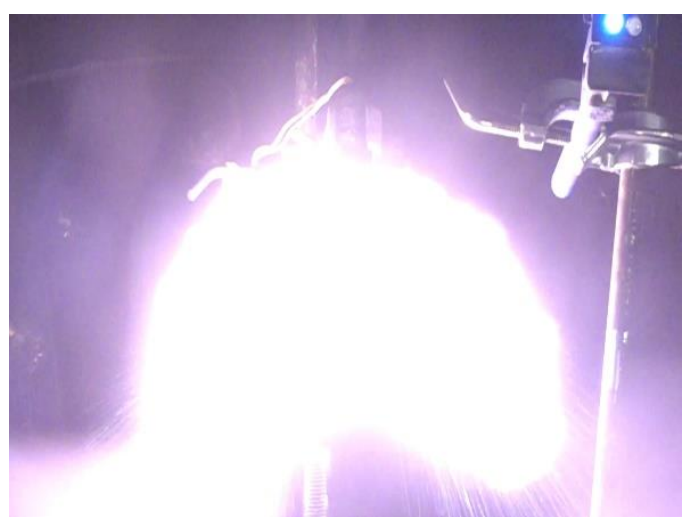

b) first visible flame after activation

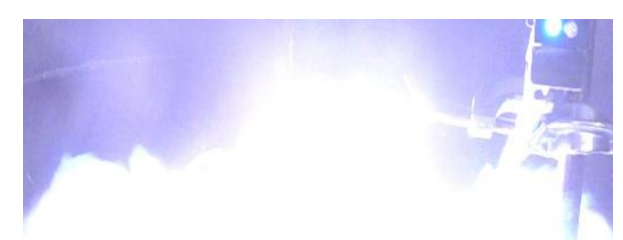

c) full flame

Fig. 5 Igniter with EPS-SO fuse head and $\mathrm{Mg} / \mathrm{KClO}_{3}$ booster burning 


\section{CONCLUSION}

The time parameter of igniter is an important factor that influences the course and result of the measurement of the dust explosion parameters. When using unconventional igniters, it is necessary to adjust the timing of activation of the dispersing process and the igniter activation.

The measurements indicate that the use of fuse head affects the igniter activation speed. The EPZ-2S produces hot particles that can ignite the pyrotechnic mixture by $11 \mathrm{~ms}$ faster. Almost the same difference $(9 \mathrm{~ms})$ was also achieved when using fuse head in the igniter. Acceleration of the EMP-SO igniter activation by $4 \mathrm{~ms}$ was achieved by using a booster. Further research in the field of lighter time parameters will be focused on the optimization of material and cover thickness, composition of the pyrotechnic mixture and the choice of the type of fuse head.

\section{Acknowledgement}

This research output was supported by the Slovak Research and Development Agency under the contract No. APVV-16-0223 and by the VEGA Project 1/1010/16.

\section{References}

[1] CONGling, J. A., MOCELLA, C.J. 2010. Chemistry of Pyrotechnics Basic Principles and Theory. 2nd ed., CRC Press Taylor \& Francis Group, Boca Raton, 225 p. ISBN 978-1-57444$740-8$

[2] KOCH, E. 2013. Pyrotechnics- Energetic Challenges. Propellants, Explosives, Pyrotechnics, 38, 603-604. ISSN 1521-4087

[3] SKAGGS, M. N. 2014. Characterization of Pyrotechnic Igniter Output with High-speed Schlieren Imaginga, PhD. thesis, Faculty of the New Mexico Institute of Mining and Technology, New Mexico Institute of Mining and Technology, Socorro, New Mexico, $161 \mathrm{p}$.

[4] ZHU, C.-G., WANG, H.-Z., MIN, L. 2014. Ignition Temperature of Magnesium Powder and Pyrotechnic Composition. Journal of Energetic Materials, 32, 219 - 226. ISSN 0737-0652

[5] SCHEID, M., KUSCHE, Ch., SCHRÖDER, V., BARTH, U., 2013. Suitability of ignition source "exploding wire" for determination of dust explosion characteristics in the 20-L-sphere. Journal of Loss Prevention in the Process Industries, 26, 1542 - 1548. ISSN 0950-4230

[6] TAVEAU J.R., GOING J.E S., HOCHGREB S., LEMKOWITZ, S.M., ROEKAERTS D. J. E. M. 2017. Igniter-induced hybrids in the 20-1 sphere. Journal of Loss Prevention in the Process Industries, 49, 348 - 356. ISSN 0950-4230

[7] YUAN J., HUANG W., DU B., KUAI N., TAN J. 2014. A New Method to Evaluate the Suitability of Ignitor Strength Used in the Tests of Dust Explosions. Applied Mechanics and Materials, 448453. 3916-3922. ISSN 1662-7482

[8] ZHEN G. and LEUCKEL W. 1997. Effects of ignitors and turbulence on dust explosions. Journal of Loss Prevention in the Process Industries, 10, 317 - 324. ISSN 0950-4230

[9] MINTZ, K. J. 1995. Problems in experimental measurements of dust explosions. Journal of Hazardous Materials, 42, 177 - 186. ISSN 0304-3894

[10] KUNDU, S.K., ZANGANEH, J., ESCHEBACH, D., MAHINPEY, N., MOGHTADERI, B. 2017. Explosion characteristics of methane-air mixtures in a spherical vessel connected with a duct. Journal of Process Safety and Environmental Protection, 111, 85-93. ISSN 0957-5820

\section{ORCID}

Richard Kuracina

Zuzana Szabová
0000-0003-1468-0820

0000-0002-7886-1623 